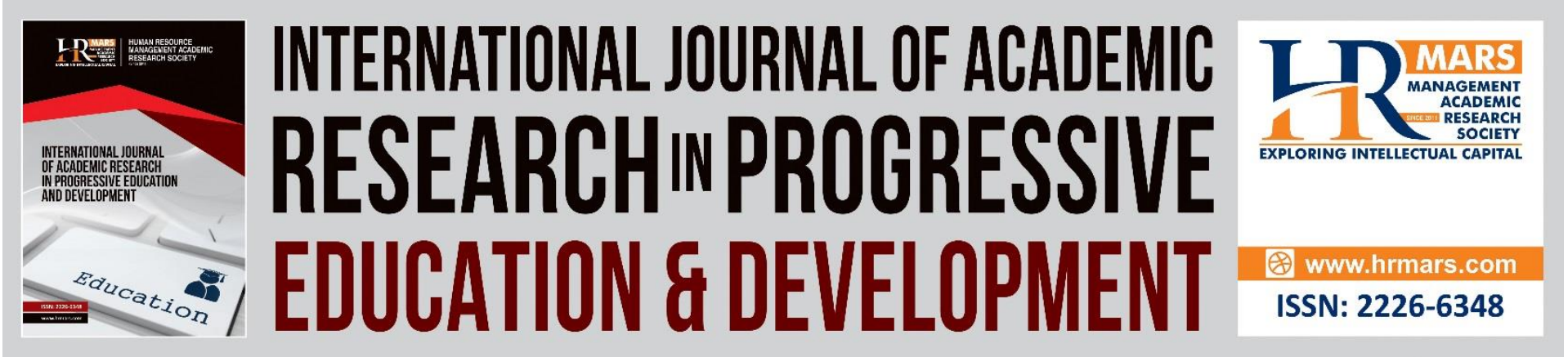

\title{
Fostering Children's Creativity Through Preschool Stem Creativity Module
}

Che Nur Farisa Che Abdul Aziz, Kamariah Abu Bakar

To Link this Article: http://dx.doi.org/10.6007/IJARPED/v10-i3/10403

DOI:10.6007/IJARPED/v10-i3/10403

Received: 07 June 2021, Revised: 12 July 2021, Accepted: 27 July 2021

Published Online: 23 August 2021

In-Text Citation: (Aziz \& Bakar, 2021)

To Cite this Article: Aziz, C. N. F. C. A., \& Bakar, K. A. (2021). Fostering Children's Creativity Through Preschool Stem Creativity Module. International Journal of Academic Research in Progressive Education and Development, 10(3), 176-189.

Copyright: (C) 2021 The Author(s)

Published by Human Resource Management Academic Research Society (www.hrmars.com)

This article is published under the Creative Commons Attribution (CC BY 4.0) license. Anyone may reproduce, distribute, translate and create derivative works of this article (for both commercial and non-commercial purposes), subject to full attribution to the original publication and authors. The full terms of this license may be seen

at: http://creativecommons.org/licences/by/4.0/legalcode

Vol. 10(3) 2021, Pg. 176 - 189

http://hrmars.com/index.php/pages/detail/IJARPED

JOURNAL HOMEPAGE

Full Terms \& Conditions of access and use can be found at http://hrmars.com/index.php/pages/detail/publication-ethics 


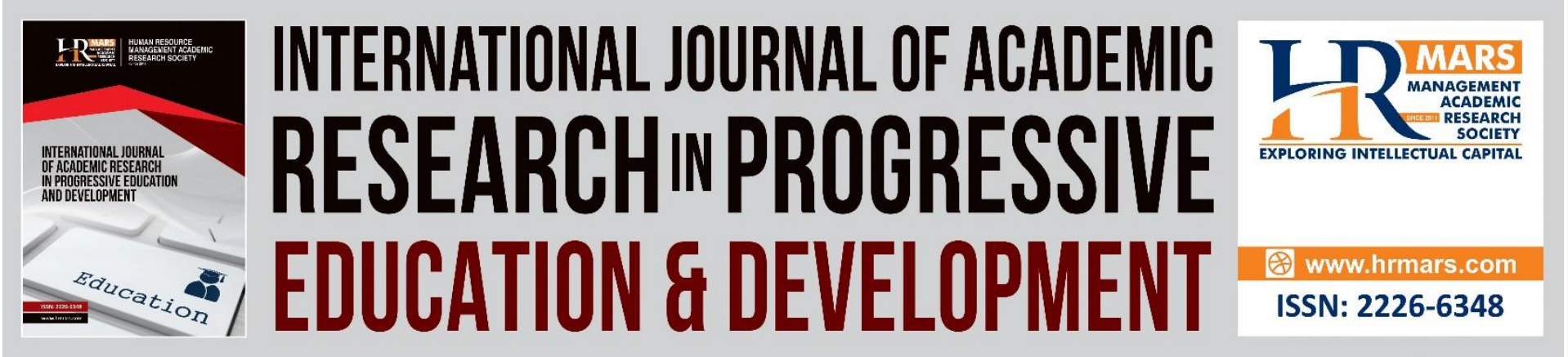

\title{
Fostering Children's Creativity Through Preschool Stem Creativity Module
}

\author{
Che Nur Farisa Che Abdul Aziz, Kamariah Abu Bakar
}

Faculty of Education, Universiti Kebangsaan Malaysia, 43600 Bangi, Selangor, Malaysia

Email:cnfarisaaziz@gmail.com,kamariah_abubakar@ukm.edu.my

\begin{abstract}
Creativity is a very important skill in 21st century education and need to be nurtured since early age. Previous researchers had claimed that creativity skills could be improved by learning Science, Technology, Engineering, and Mathematics (STEM). However, less attention is given towards fostering creativity through STEM in preschool. Therefore, this study aimed to identify the potential contributions of Preschool STEM Creativity Module on creativity development among preschool children. In this quasi-experimental study, 30 children (aged 6 years old) were divided into experimental and control groups. In the experimental group, the researchers fostered children's creativity through Preschool STEM Creativity Module. Creativity Test was used as an instrument to assess creativity development and the level of creativity through four dimensions of creativity namely fluency, flexibility, originality, and elaboration. Scores for pre and post-tests were analyzed using descriptive, independent $t$ test, paired sample t-test, and Wilcoxon test. The results were indicated that the Preschool STEM Creativity Module intervention have led to a positive impact on the development of children's creativity. Furthermore, this study had also found that the intervention of this module could help to improve the level of creativity among children in terms of flexibility, fluency, originality and elaboration. Nevertheless, the improvement in fluency for the experimental group was seen to be lower when compared to the control group. Even so, in overall, STEM learning has been found to contribute to preschool children's creativity. And due to that reason, STEM learning should be implemented into the preschool curriculum in responds to the national education initiatives by strengthening STEM and achieving the 21st century skills.
\end{abstract}

Keywords: Children, Creativity, Learning, Preschool, STEM

\section{Introduction}

Creativity is one of the main foundations that should be learned and possessed by every human capital be it children, adolescents or adults. Creativity is one of the essential elements in 21st century education (OECD, 2020) and it is also considered an indispensable ability in social life so that the society is able to face the challenges and the increasingly complex global competition in the future (Altan \& Tan, 2020). In this regard, UNESCO also stressed that children should be encouraged to improve their creativity. Neurologically, the right time to 
stimulate brain is at the early stages of childhood so that creative and innovative thinkers can be produced in the future (Leggett, 2017). Vygotsky stated that all human beings including young children have the ability to produce creativity (Lindqvist, 2003). Guilford (1967) argued that a person's level of creativity is seen in creativity development in four dimensions, namely fluency, flexibility, originality and elaboration.

In order to achieve the success of 21st century, STEM is an alternative learning to develop creative, logical, innovative and productive thinking skills (Sirajudin et al., 2021). STEM is an acronym that combines the fields of Science, Technology, Engineering and Mathematics which is an initiative of the National Science Foundation (NSF) in the United States (Rasul et al., 2018). STEM emphasizes practical and reality aspects involving gamebased learning, inquiry and project-based learning (Harris \& De Bruin, 2018; Hussin et al., 2019; Ong et al., 2016) by providing real experiences to the children. STEM is found to be suitable for implementation among preschool children and must be applied from the beginning of education in order to unearth children's interests, talents and improve their development (Ong et al., 2016).

In line with current development, STEM education is an alternative learning method that can be used to enhance creativity in this century (Harris \& De Bruin, 2018; Sirajudin et al., 2021). In addition, STEM is also one of the most important approaches to unearth creativity among children (Altan \& Tan, 2020). Through STEM learning that involves natural environments and real-world experiences, children are able to explore and widely open their mind. However, less studies have been conducted in relation with fostering creativity through STEM among preschool children because most previous studies focused more on the context of students in primary schools (Conradty \& Bogner, 2019; Conradty et al., 2020) secondary schools (Altan \& Tan, 2020; Rasul et al., 2018) and universities (Kuo et al., 2019; Sirajudin et al., 2021).

The Ministry of Education (2013) reported that students were less able to practise knowledge and critical thinking outside the academic context because thinking skills are given less attention in education. In the meantime, previous studies in Malaysia (Adnan et al., 2016; Baharin et al., 2018; Hussin et al., 2019) placed less emphasis on fostering creativity in STEM education. Instead, most studies focused on the effectiveness of STEM education implementation. This is because STEM education is still at a new stage in Malaysia and faces several major challenges in terms of the readiness of teachers and students (Baharin et al., 2018). Poor teachers' mastery of science learning pedagogy, lack of teaching aids as well as children's limited knowledge and varied interests are the challenges of implementing STEM education at preschool level (Daud, 2019).

Therefore, Preschool STEM Creativity Module has been developed to be used as a guide for preschool teachers in planning STEM teaching and learning that can stimulate and enhance children's creativity. Module development by providing well-planned programs is one way to support preschool education to foster creativity in young children (Bai et al., 2020). Therefore, this study aimed to identify potential contributions of this module towards the development of creativity of preschool children. This study will answer two research questions, namely: 1) Will children's creativity skills be improved by integrating STEM through Preschool Creativity STEM Module? 2) What is the extent of children's creativity level based on the four dimensions of creativity (fluency, flexibility, originality and elaboration)? 


\section{Literature Review}

Creativity is defined as something new, unprecedented and serves as a solution to a problem (Guilford, 1967) to fill the information gap in formulating, testing and transforming new ideas (Torrance, 1977). Creativity is one of the essential skills in the 21st century, in which the ability to think creatively to solve problem is highly needed. This has led education systems around the world to find ways to foster creativity in children (Bai et al., 2020). The Ministry of Education, Malaysia has defined creative thinking skills in 21st century education to include 10 elements, namely generating ideas, making connections, making inferences, predicting, making hypotheses, synthesizing, generalizing, imagining, making analogy and creating. To ensure that an individual is capable of creative thinking and have creativity skills, each individual needs to learn how to acquire knowledge throughout life so they can connect various knowledge and create new knowledge (Kementerian Pendidikan Malaysia, 2013).

Guilford proposed the Structure of Intellect (SOI) model which presents 24 types of divergent thinking to be used in assessing creativity (Altan \& Tan, 2020). Divergent thinking is the ability to create a variety of new ideas or knowledge from the existing knowledge to solve a problem (Guilford, 1967). Preliminary studies by Guilford on divergent thinking tests and the SOI models had introduced dimensions of creativity that include fluency, flexibility, originality, and elaboration. The first dimension; fluency refers to the number of ideas, solutions, or answers generated (Altan \& Tan, 2020; Bai et al., 2020). The second dimension; flexibility refers to the number of ideas produced in different categories (Gu et al., 2019). The third dimension; originality refers to the uniqueness of an idea, in which a high score on this dimension means the ability to produce thoughts that are original and different from others (Gong et al., 2020). Finally the fourth dimension; elaboration refers to the ability to elaborate the ideas produced in detail (Guilford, 1967).

Several studies had evaluated the effectiveness of STEM approaches on creativity development. In Western countries, several researchers have developed STEM integration module for all levels of education including preschool (Bicer et al., 2019; Conradty \& Bogner, 2019; Conradty et al., 2020; Kewalramani et al., 2020; Stylianidou et al., 2018) and they have successfully proven that STEM module interventions can improve students' thinking skill and creativity. Similarly, several studies in Eastern countries (B Budi Setiawan et al., 2020; Kuo et al., 2019; Rasul et al., 2018; Shukri et al., 2019; Siew \& Norjanah Ambo, 2018; Sirajudin et al., 2021 ) indicated that STEM approaches have a positive effect in developing and empowering creative thinking among elementary, secondary and universities students. Nevertheless, less modules have been developed in fostering creativity through STEM among preschool children.

Previous research has been established after participating in STEM project-based learning, students had more positive attitudes toward divergent thinking and had a better self-perception of their creative problem-solving skills (B Budi Setiawan et al., 2020; Bicer et al., 2019; Rasul et al., 2018; Shukri et al., 2019). The STEM project-based learning requires students to generate and connect ideas to their existing knowledge, which can foster creative thinking and creativity; an essential element in this century (Shukri et al., 2019). In another study, Conradty and Bogner (2019) found that STEM inquiry-based learning produced longterm knowledge and consistent intrinsic motivation score, but no single STEM intervention increased self-reported dimensions of creativity. Similarly, Sirajudin et al. (2021) revealed that student's creativity varies between low and moderate and the findings to the creativity tests given showed lower-than-expected results. However, the study suggested that STEM 
should be used as an alternative and approach in biology learning, especially in improving creative thinking ability. Furthermore, consistent training in an adequate sociocultural setting is required to foster creativity sustainably (Conradty \& Bogner, 2019).

Accordingly, STEM approach in teaching and learning process can increase the level of creativity, fluency, flexibility, originality and elaboration (Kuo et al., 2019). The study found that originality increased significantly compared to flexibility, fluency and elaboration after performing STEM interventions using a project-based learning approach. Moreover, the study revealed that interdisciplinary collaboration can significantly assist students in coming up with more creative ideas and developing or refining their design concepts. However, this is in contrast with the study by Altan and Tan (2020), in which students showed a higher improvement in fluency, while originality increased at a lower level. This is because students' ideas are influenced by several factors including exposure to other students' ideas and familiarity with the design-based learning process.

In addition, children's levels of creativity can be enhanced through effective and fun learning interventions due to the increase in creativity, originality, fluency, flexibility and elaboration among children (Bai et al., 2020; Gong et al., 2020). A study by Bai et al. (2020), which measured creativity using the Torrance Test of Creative Thinking on 155 children aged 4 to 6 , found an increased in originality and elaboration after the intervention was conducted. Children developed spontaneously in elaboration skills through two pedagogical processes in intervention which explained their ideas to both peers and teachers in most activities and collaborative teamwork. Whereas, Gong et al. (2020) found that 4-year-old children showed an increased in originality and fluency. The study revealed that intervention of open-learning environment stimulated children's curiosity and eagerness to explore, both which are important to their long-term and deep involvement. Furthermore, an intervention programme that explicitly (and intensively) encouraged children to generate, express, and share novel ideas may have a significant impact to creativity development (Bai et al., 2020; Gong et al., 2020).

Meanwhile, Leggett (2017) revealed that some teachers had misconceptions about children's creative thinking during learning activities and a lack of relationship between the teacher's role and children's creative thinking. In addition, the implementation of STEM education is difficult in preschools due to several challenges faced by the teachers (Daud, 2019). The study found three main challenges namely a) teachers who are lack of knowledge in science teaching methods, b) the lack of materials to conduct investigative activities, especially individual hands-on activities, and c) children who are lack of focus and lose mood during the learning process. Therefore, this study is expected to provide support and guidance, especially in the field of STEM to the preschool teachers in order to improve the quality of teaching and learning process in educating preschool children.

\section{Preschool STEM Creativity Module}

Preschool STEM Creativity Module is developed based on creative thinking component contained in the thinking skills presented by the Curriculum Development Center and Teacher Education Division. There are 10 elements in creative thinking. However, this module only involves 5 elements, namely idea generation skill, connection-making skill, inference- making skill, predictive skill and creating skill. Nevertheless, the researchers combined connectionmaking skill and inference-making skills in one theme and made a total of four themes in this module. This module is based on the theory of constructivism from Piaget and Vygotsky which 
supports several common perspectives namely student-centered approach, experiential learning, collaborative learning, problem-solving process and social environment (Shukri et al., 2019).

In addition, the construction of Preschool STEM Creativity Module is guided by the Preschool Curriculum Standard Document which highlights project-based learning, inquirybased learning and play-based learning as teaching and learning methods appropriate to children's developmental levels. Project-based learning involves activities that stimulate curiosity, imagination, challenge and problem-solving. Inquiry-based learning gives children the opportunity to share ideas, explore and ask some questions to learn about something, especially things that have just been discovered. Playing gives the opportunity for children to explore, investigate, gain new knowledge and build new experiences. Children can improve their skills and knowledge especially in the field of STEM when given exposure to toys or materials related to STEM.

\section{Methodology \\ Research Design}

This was a quasi-experimental study using a quantitative approach to test the impact of Preschool STEM Creativity Module developed to foster creativity in children. A quasiexperiment is an assessment to determine whether an intervention such as the Preschool STEM Creativity Module can have an impact on the sample studied (George, 2006). The pretests were given before the start of teaching and learning using the Preschool STEM Creativity Module and then post-tests were conducted after two weeks of intervention. Meanwhile, teaching and learning of children in the control group were taught using the conventional methods. Conventional methods are teaching and learning that do not use modules, instead, it is a teacher-centered learning (Shukri et al., 2019).

\section{Study Sample}

The study involved a total of 30 children aged 6 and two teachers in one of the kindergartens in Kuala Lumpur, Malaysia. Cluster random sampling was used in sample selection. The researchers had identified two classes for the experimental group and the control group. These two groups consisted of 15 children each.

\section{Instruments}

Research instruments were used to collect the data required in this study. This study involved empirical data collected using Creativity Test scores. This instrument was adapted from the Torrance Test of Creative Thinking-Figural (TTCT-F) by (Torrance, 1977). The Creativity Test involved measurements for creativity dimensions of fluency, flexibility, originality and elaboration. These four dimensions are necessary for an individual to become a creative thinker (Guilford, 1967). Regarding the test-retest reliability, the correlation coefficients were between 0.521 and 0.588 , reaching a level of significance. A reliability value of 0.5 is desirable for group and research applications given the complexity of creative thinking (Treffinger, 1985). The low test-retest scores were likely due to the role of emotions, motivation and situational context in creative performance as well as a decrease in children's interest in drawing (Kālis et al., 2016). Regarding internal consistency reliability, the Cronbach's Alpha values for all scores were between 0.578 and 0.740 . These estimates were unsurprising because the scores involved a small number of items (Bicer et al., 2019). Hence, the study 
sample was considered adequate for the exploratory purpose of this study. The Creativity Test comprised two forms, namely the pre-test and post-test. Both tests involved two similar tasks which were composing a drawing and completing a drawing on repeated lines. In the first task, the children were asked to make as many drawings as possible on a paper with circles. In the second task, the children were asked to complete the drawing using a series of 9 repeated lines. In each task, the children were asked to give the pictures a title. The researcher and the teachers helped the children to write the titles that the children suggested. The time limit for both tasks was 10 minutes.

\section{Data Collection Procedures}

The study was conducted during the period of Movement Control Order due to Covid-19. Therefore, preschool children had to be divided into two groups for school day rotation purpose. As a result, this study could only be carried out in two weeks by implementing 4 activities out of 16 activities contained in the module. Nevertheless, each activity represented 4 main themes, namely the skills of generating ideas, connection-making and inferencesmaking skills, the skills of predictive skills and creating skills. Each activity was conducted by a teacher who was given initial exposure through a three-day Preschool STEM Creativity Module workshop. The teachers conducted these activities under the supervision of the researcher. All children involved in both groups took the pre and post-tests, but only children from the experimental group were involved in the implementation of the module. The pre and post-tests were conducted the day before and the day after the implementation of Preschool STEM Creativity Module.

\section{Data Analysis Methods}

The level of creativity in the Creativity Test was calculated in terms of the four dimensions namely fluency, flexibility, originality and elaboration. Fluency scores represent the number of ideas generated. The flexibility score is based on the number of various ideas produced by each child. The originality score represents the number of ideas that are different from others and the description score is calculated based on the details of ideas generated. Researchers performed descriptive quantitative analysis of mean, standard deviation, normality test, independent T-test, paired sample t-test for normally distributed data and Wilcoxon test for abnormally distributed data to study the effectiveness of module interventions on children's creativity skills.

\section{Findings}

This study aimed to identify the impact of the use of Preschool Creativity STEM Module on creativity development of preschool children. The results of this study were divided into two parts. The first part was to answer the research question; "Will children's creativity skills be improved through the implementation of teaching using Preschool Creativity STEM Module?" The second part displays the level of children's creativity based on the four dimensions of creativity.

\section{The Effect of the Use of Preschool Creativity STEM Module on Creativity Development of Preschool Children}

Creativity Tests were conducted before and after the module intervention to identify whether the Preschool STEM Creativity Module would influence children's creativity. The results of the study on creativity development of preschool children are shown in Table 1 . Children's 
creativity skills for the experimental group showed that the mean pre-test score, which was 24.80 was higher than the control group with a difference of 3.33. However, the independent T-test showed no significant difference in the pre-test scores between the experimental group ( $n=15, M=24.80, S D=6.46)$ and the control group $(n=15, M=21.47, S D=6.16)$ with $t(15)$ $=1.45, \mathrm{p}>.05$. Accordingly, both groups showed an increase in the mean post-test score of 35.07 for the experimental group and 27.40 for the control group.

Table 1: Mean, Standard Deviation and Independent T-Test Results for Children's Creativity Skills Scores in Pre and Post-Tests.

\begin{tabular}{ccccccc}
\hline Test & Group & Frequency & Mean & Std. Deviation & $\mathrm{t}$ & Significant \\
\hline \multirow{2}{*}{ Pre Test } & Experiment & 15 & 24.80 & 6.46 & 1.45 & 0.159 \\
& Control & 15 & 21.47 & 6.16 & & \\
\multirow{2}{*}{ Post Test } & Experiment & 15 & 35.07 & 6.22 & 3.02 & 0.005 \\
& Control & 15 & 27.40 & 7.61 & & \\
\hline
\end{tabular}

The experimental group showed an improvement difference of 10.27 higher than the control group of 5.93. Independent T-test showed that there was a significant difference in the posttest score between the experimental group $(n=15, M=35.07, S D=6.22)$ and the control group $(n=15, M=27.40, S D=7.61)$ with $t(15)=3.02, p<.05$.

\section{Level of creativity of preschool children}

The level of children's creativity is seen from the four dimensions of creativity, namely fluency, flexibility, originality and elaboration (Guilford, 1962). Table 2 shows the descriptive mean and standard deviation in the pre and post-tests for each of creativity variables between the experimental and control groups. Whereas, the mean differences for the pre and post-test scores in the four dimensions of creativity in experimental and control groups can be seen in Figure 1 below.

Table 2: Descriptive Data of Pre and Post-Tests for Four Dimensions of Creativity in Experimental and Control Groups.

\begin{tabular}{cccccccccc}
\hline & & \multicolumn{2}{c}{ Fluency } & \multicolumn{2}{c}{ Flexibility } & \multicolumn{2}{c}{ Originality } & \multicolumn{2}{c}{$\begin{array}{c}\text { Elaboration } \\
\text { Test }\end{array}$} \\
& Group & Mean & $\begin{array}{c}\text { Std. } \\
\text { Deviation }\end{array}$ & Mean & $\begin{array}{c}\text { Std. } \\
\text { Deviatio } \\
\mathrm{n}\end{array}$ & Mean & $\begin{array}{c}\text { Std. } \\
\text { Deviatio } \\
\mathrm{n}\end{array}$ & Mean & $\begin{array}{c}\text { Std. } \\
\text { Deviatio } \\
\mathrm{n}\end{array}$ \\
\hline Pre & Experiment & 11.53 & 3.23 & 6.93 & 3.17 & 2.80 & 0.68 & 3.53 & 1.46 \\
Test & Control & 9.33 & 2.72 & 6.27 & 2.55 & 2.80 & 1.08 & 3.07 & 1.22 \\
Post & Experiment & 14.13 & 1.64 & 10.40 & 3.22 & 5.53 & 2.00 & 5.00 & 1.93 \\
Test & Control & 12.07 & 2.52 & 7.53 & 3.72 & 3.93 & 1.62 & 3.87 & 1.88 \\
\hline
\end{tabular}


INTERNATIONAL JOURNAL OF ACADEMIC RESEARCH IN PROGRESSIVE EDUCATION AND

DEVELOPMENT

Vol. 10, No. 3, 2021, E-ISSN: 2226-6348 @ 2021 HRMARS

Figure 1. Mean Differences of Pre and Post-Tests between Experimental and Control Groups

Dimensions of Creativity

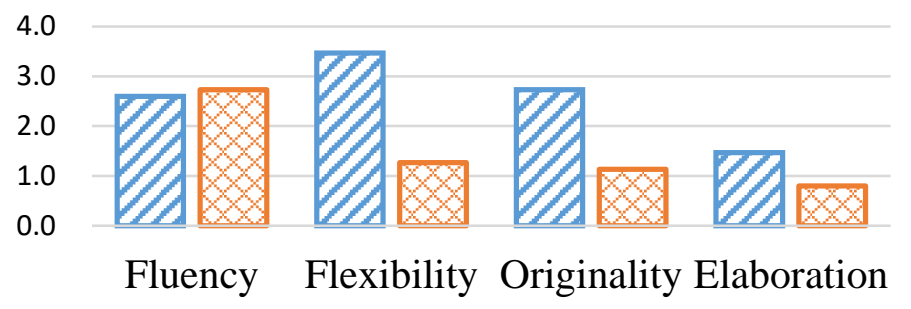

$\square$ Experimental $\Delta$ Control

Testing the data for normal distribution is important before the data are analyzed inferentially. The normal distribution of data was in the range of -2 to +2 (George, 2006). Table 3 shows that the skewness and kurtosis values of pre and post-test differences for each dimension in the two groups were in the range. However, Shapiro-Wilk normality test showed that the score differences for dimensions of fluency for the experimental group $(p=0.009)$, fluency of the control group ( $p=0.028$ ) and originality of the experimental group $(p=0.043)$ were abnormally distributed, $p<.05$. Researchers chose Shapiro-Wilk test as this test is appropriate when it involves a sample size for each group of less than 50 (George, 2006). As such, this study used a paired T-Test for normally distributed data and a Wilcoxon test for abnormally distributed data.

Table 3: Normally Distributed Data Testing and Normality Test for Score Differences in Pre and Post- Test between Experimental and Control Groups

\begin{tabular}{ccccc}
\hline \multirow{2}{*}{ Dimensions } & Group & Skewness & Kurtosis & Shapiro-Wilk \\
\cline { 5 - 5 } & & & & Sig. \\
\hline Fluency & Experiment & 0.724 & -1.032 & 0.009 \\
& Control & 0.563 & -1.186 & 0.028 \\
Originality & Experiment & 0.449 & -0.278 & 0.584 \\
& Control & 0.459 & 0.232 & 0.713 \\
Elaboration & Experiment & 1.171 & 1.376 & 0.043 \\
& Control & -0.588 & -0.437 & 0.070 \\
& Experiment & 0.236 & -0.632 & 0.148 \\
& Control & 0.603 & 0.675 & 0.159 \\
\hline
\end{tabular}

Based on Table 4, the children's post-test scores generally showed an improvement in creativity skills. The results of the study found that there was a significant difference between the flexibility scores of the children in experimental group before and after the module intervention with $\mathrm{t}(14)=-3.856, \mathrm{p}<.05$. In terms of mean, the children's flexibility score after the intervention ( $M=10.40$ ) was higher than the flexibility score before the intervention ( $M$ $=6.93$ ). For elaboration dimension, the mean score of children in the experimental group for the pre-test was $M=3.53$ and increased to $M=5.00$. 
Table 4: Paired T-Test Comparing the Pre and Post-Test Scores for Each Dimension of Creativity (Experimental and Control Group)

\begin{tabular}{|c|c|c|c|c|c|c|c|c|c|}
\hline \multirow{3}{*}{ Group } & \multirow{3}{*}{ Dimensions } & \multicolumn{5}{|c|}{ Paired Differences } & \multirow[b]{3}{*}{$t$} & \multirow[b]{3}{*}{ df } & \multirow{3}{*}{$\begin{array}{l}\text { Sig. } \\
(2- \\
\text { tailed })\end{array}$} \\
\hline & & \multirow[b]{2}{*}{ Mean } & \multirow{2}{*}{$\begin{array}{c}\text { Std. } \\
\text { Deviatio } \\
\mathrm{n}\end{array}$} & \multirow{2}{*}{$\begin{array}{l}\text { Std. } \\
\text { Error } \\
\text { Mean }\end{array}$} & \multicolumn{2}{|c|}{$\begin{array}{c}\text { 95\% Confidence } \\
\text { Interval of the } \\
\text { Difference }\end{array}$} & & & \\
\hline & & & & & Lower & Upper & & & \\
\hline \multirow[t]{2}{*}{ Experiment } & $\begin{array}{l}\text { Flexibility Pre-test - } \\
\text { Flexibility Post-test }\end{array}$ & -3.467 & 3.482 & .899 & -5.395 & -1.538 & -3.856 & 14 & .002 \\
\hline & $\begin{array}{l}\text { Elaboration Pre- } \\
\text { test - Elaboration } \\
\text { Post-test }\end{array}$ & -1.467 & 1.642 & .424 & -2.376 & -.558 & -3.460 & 14 & .004 \\
\hline \multirow[t]{4}{*}{ Control } & $\begin{array}{l}\text { Flexibility Pre-test - } \\
\text { Flexibility Post-test }\end{array}$ & -1.267 & 2.658 & .686 & -2.739 & .205 & -1.845 & 14 & .086 \\
\hline & Originality Pre-test & & & & & & & & \\
\hline & $\begin{array}{l}\text { - Originality Post- } \\
\text { test }\end{array}$ & -1.133 & 1.187 & .307 & -1.791 & -.476 & -3.697 & 14 & .002 \\
\hline & $\begin{array}{l}\text { Elaboration Pre- } \\
\text { test - Elaboration } \\
\text { Post-test }\end{array}$ & -.800 & 1.373 & .355 & -1.560 & -.040 & -2.256 & 14 & .041 \\
\hline
\end{tabular}

The difference between pre-test and post-test was significant with $t(14)=-3.460, p<.05$. Accordingly, the results of the study found that there was no significant difference between the pre and post-test flexibility scores for control group with $t(14)=-1.845, p>.05$. For originality dimension, the mean score of children in the control group for pre-test was $M=$ 2.80 and increased to $M=3.72$. The difference between pre-test and post-test was significant with $t(14)=-3.697, p<.05$. For elaboration dimension, the mean score of children in the control group for pre-test was $M=3.07$ and increased to $M=3.87$. The difference between pre-test and post-test was significant with $t(14)=-2.256, p<.05$.

Wilcoxon test was used when Shapiro-Wilk test showed that the data distribution was abnormal for dimensions of fluency and originality in the experimental group and fluency in the control group. After conducting Wilcoxon test analysis, the findings showed the existence of a significant fluency score difference in the experimental group between pre-test and posttest with $Z=2.820, p<.05$. As for originality dimension, the results of the study found that there was a significant difference in the experimental group between the pre and post-tests with $Z=3.425, p<.05$. Meanwhile, the results of the study also found that there was a significant difference in dimension of fluency in the control group between pre and post-tests with $\mathrm{Z}=-3.078, \mathrm{p}<.05$.

Table 5: Wilcoxon Test Comparing the Pre and Post-Test Scores for Each Dimension of Creativity (Experimental and Control Group)

\begin{tabular}{clcc}
\hline Group & \multicolumn{1}{c}{ Dimensions } & $\mathrm{Z}$ & Asymp. Sig. (2-tailed) \\
\hline Experiment & Fluency Post-test - Fluency Pre-test & $-2.820^{\mathrm{b}}$ & .005 \\
& Originality Post-test - Originality Pre-test & $-3.425^{\mathrm{b}}$ & .001 \\
Control & Fluency Post-test - Fluency Pre-test & $-3.078^{\mathrm{b}}$ & .002 \\
\hline
\end{tabular}




\section{Discussion and Implications}

In this study, the effect of Preschool STEM Creativity Module on creativity development of preschool children was studied. The results of this study are in line with the findings of previous research (B Budi Setiawan et al., 2020; Bicer et al., 2019; Conradty et al., 2020; Kewalramani et al., 2020; Rasul et al., 2018; Shukri et al., 2019; Siew \& Norjanah Ambo, 2018). They reported that STEM integration had an impact on improving creative thinking. Based on the findings of this study, there were significant differences in the post-test scores between the experimental group and the control group. This indicates that teaching and learning using Preschool STEM Creativity Module and conventional methods have a positive impact on the development of children's creativity. However, the results of the study found that creativity development of children in the experimental group was higher than the children in the control group. Therefore, teaching and learning methods that use Preschool STEM Creativity Module are more effective than conventional methods in improving children's creativity skills.

Preschool STEM Creativity Module which includes the elements of creative thinking such as creativity skills of generating ideas, making inferences and connection, predicting and creating leads to an improvement in children's creativity development. This module provides STEM teaching and learning activities that are fun, easy and appropriate for the developmental level of children of age four to six. Through this study, children can be seen as enthusiastic and fully focused when teaching and learning activities were carried out. The use of this module assists teachers in training children to think creatively by investigating, researching and studying about a discovery and then connecting the idea with a variety of materials available in their environment. The implementation of this module has proven that STEM is the most important approach to unearth creativity among children (Altan \& Tan, 2020).

The results of the paired T-test and Wilcoxon test showed that the group of children given the Preschool STEM Creativity Module intervention and the control group showed better performance on the four dimensions of creativity in the post-test compared to the pretest. Nonetheless, children who were taught using the Preschool STEM Creativity Module were found to have significantly higher improvement scores compared to the children taught using the conventional method in the control group. The results of this study are in line with Kuo et al (2019) and (Siew \& Norjanah Ambo, 2018), which also found that teaching and learning using STEM approaches can improve fluency, flexibility, originality and elaboration. In addition, this study is consistent with previous studies which found the dimensions of fluency, originality, flexibility and elaboration among children improved after interesting and fun teaching and learning intervention were introduced (Bai et al., 2020; Gong et al., 2020).

Meanwhile, the findings of this study contradict Altan and Tan (2020), which found that fluency increased higher after the post-test. This study found that the variance of flexibility scores for the experimental group increased higher followed by originality, fluency and elaboration. This suggests that children are able to make more connections between ideas by producing a variety of appropriate alternatives (Kuo et al., 2019). However, a high increase in flexibility is not enough to draw a strong conclusion on the development of children's creativity. Guilford (1967) and Torrance (1977) argue that the other three dimensions of creativity, namely originality, fluency and elaboration are also important for children to achieve a great improvement in all four dimensions in order to be known as a creative person. 
This study has proven that children should be exposed to STEM approaches at the preschool level in order to cultivate their creativity and interest more deeply. This is because children basically have an instinct of wanting to learn new things, ask various questions, try something new as well as having a strong memory. Accordingly, Preschool STEM Creativity Module also uses project-based learning, inquiry-based learning and play-based learning approaches so that the modules are appropriate for children's developmental levels to nurture and enhance their creativity. Along with the 21 st century skills, fostering creativity at the preschool level will indirectly improve thinking skills and have a positive impact on children's future (Altan \& Tan, 2020; Gong et al., 2020; Harris \& De Bruin, 2018).

In addition, this study is expected to make the implementers, especially the preschool teachers, aware of the need to consider more effective teaching methods and strive to respond to the national education initiatives by strengthening STEM and achieving the 21st century skills. The development of Preschool STEM Creativity Module is one of the initiatives to address the issues and challenges of preschool teachers in implementing STEM by providing descriptions and methods of implementing STEM teaching and learning according to the National Preschool Standard Curriculum.

In addition, the researcher hopes that this study can also help and encourage parents to do activities with children at home, especially during the Movement Control Order (MCO) when the country is being hit by COVID-19 pandemic, in which parents and children can spend time together doing a variety of activities using the Preschool STEM Creativity Module. In addition, the results of this study are also expected to be of use by the Ministry of Education in strengthening STEM teaching and learning process at the preschool level in Malaysia to enhance the development of children's creativity.

\section{Conclusion}

This study examined the potential contributions of Preschool STEM Creativity Module towards creativity development of preschool children using a quasi-experimental design. This module is specifically designed to foster creativity among preschool children. The results of the study found that the implementation of Preschool STEM Creativity Module has a positive effect on the development of children's creativity. The study also showed that the level of children's creativity in terms of creativity dimensions such as flexibility, fluency, originality and elaboration also increased. However, the improvement in fluency for experimental group was seen to be low compared to the control group. This is because a child's creativity fluency is likely to be influenced by several factors including the length of time set when conducting a creativity test. The results of this study have significant implications on understanding the integration of Science, Technology, Engineering and Mathematics as an approach for effective teaching and learning methods to foster creativity.

Overall, the results of this study indicate that the Preschool STEM Creativity Module has the potential to foster creativity among preschool children. The limitation of this study is the short and limited implementation period of the module due to the Movement Control Order because of Covid-19. Despite its limitations, this study still adds to the understanding of effective teaching and learning methods to enhance the development of children's creativity. In addition, researchers would like to suggest that the nurturing of creativity among preschool children through STEM approach should be measured with several other instruments to ensure that STEM is an appropriate approach to enhance the level of creativity of children. Researchers also suggested that a study on the views of preschool teachers on 
DEVELOPMENT

Vol. 10, No. 3, 2021, E-ISSN: 2226-6348 @ 2021 HRMARS

Preschool STEM Creativity Module to be conducted to further strengthen the effectiveness of this module in nurturing children's creativity. Continuous effort is required to ensure the development of children's creativity can be nurtured from the beginning of education.

\section{References}

Adnan, M., Ayob, A., Ong, E. T., Ibrahim, M. N., Ishak, N., \& Sheriff, J. (2016). Memperkasa pembangunan modal insan Malaysia di peringkat kanak-kanak: Kajian kebolehlaksanaan dan kebolehintegrasian pendidikan STEM dalam kurikulum PERMATA Negara. Geografia: Malaysian Journal of Society Space, 12(1), 29-36.

Altan, E. B., \& Tan, S. (2020). Concepts of creativity in design based learning in STEM education. International Journal of Technology Design Education, 1-27. https://doi.org/https://doi.org/10.1007/s10798-020-09569-y

Baharin, N., Kamarudin, N., \& Manaf, U. K. A. (2018). Integrating STEM education approach in enhancing higher order thinking skills. International Journal of Academic Research in Business Social Sciences, 8(7), 810-821.

Bai, H., Duan, H., Kroesbergen, E. H., Leseman, P. P. M., \& Hu, W. (2020). The Benefits of the Learn to Think Program for Preschoolers' Creativity: An Explorative Study [Article]. Journal of Creative Behavior, 54(3), 699-711. https://doi.org/10.1002/jocb.404

Bicer, A., Lee, Y., Capraro, R. M., Capraro, M. M., Barroso, L. R., \& Rugh, M. (2019). Examining the Effects of STEM PBL on Students' Divergent Thinking Attitudes Related to Creative Problem Solving. 2019 IEEE Frontiers in Education Conference (FIE),

Conradty, C., \& Bogner, F. X. (2019). From STEM to STEAM: Cracking the code? How creativity \& motivation interacts with inquiry-based learning. Creativity Research Journal, 31(3), 284-295. https://doi.org/https://doi.org/10.1080/10400419.2019.1641678

Conradty, C., Sotiriou, S. A., \& Bogner, F. X. (2020). How creativity in STEAM modules intervenes with self-efficacy and motivation. Education Sciences, 10(3), 70. https://doi.org/https://doi.org/10.3390/educsci10030070

Daud, K. M. (2019). Cabaran guru prasekolah dalam menerapkan Pendidikan Stem. Jurnal Pendidikan Sains Dan Matematik Malaysia, 9(2), 25-34. https://doi.org/https://doi.org/10.37134/jpsmm.vol9.2.4.2019

George, D. (2006). SPSS for Windows step by step : a simple guide and reference. In (Vol. 13.0 update, pp. 0-2): Pearson Education India.

Gong, X., Zhang, X., \& Tsang, M. C. (2020). Creativity development in preschoolers: The effects of children's museum visits and other education environment factors [Article]. Studies in Educational Evaluation, 67, Article 100932.

https://doi.org/10.1016/j.stueduc.2020.100932

Gu, X., Dijksterhuis, A., \& Ritter, S. M. (2019). Fostering children's creative thinking skills with the 5-I training program. Thinking Skills and Creativity, 32, 92-101. https://doi.org/https://doi.org/10.1016/j.tsc.2019.05.002

Guilford, J. P. (1962). Potentiality for creativity. Gifted Child Quarterly, 6(3), 87-90.

Guilford, J. P. (1967). Creativity: Yesterday, today and tomorrow. The Journal of Creative Behavior, 1(1), 3-14.

Harris, A., \& De Bruin, L. (2018). An international study of creative pedagogies in practice in secondary schools: Toward a creative ecology. Journal of Curriculum Pedagogy, 15(2), 215-235. https://doi.org/https://doi.org/10.1080/15505170.2018.1457999 
Hussin, H., Jiea, P. Y., Rosly, R. N. R., \& Omar, S. R. (2019). Integrated 21st Century Science, Technology, Engineering, Mathematics (Stem) Education Through Robotics ProjectBased Learning. Humanities Social Sciences Reviews, 7(2), 204-211. https://doi.org///doi.org/10.18510/hssr.2019.7222

Kālis, E., Roḳe, L., \& Krūminna, I. (2016). Investigation of psychometric properties of the test for creative thinking-Drawing production: Evidence from study in Latvia. The Journal of Creative Behavior, 50(1), 47-63.

Kementerian Pendidikan Malaysia. (2013). Pelan Pembangunan Pendidikan Malaysia 2013 2025.

Kewalramani, S., Palaiologou, I., \& Dardanou, M. (2020). Children's engineering design thinking processes: The magic of the ROBOTS and the power of BLOCKS (electronics) [Article]. Eurasia Journal of Mathematics, Science and Technology Education, 16(3). https://doi.org/10.29333/ejmste/113247

Kuo, H. C., Tseng, Y. C., \& Yang, Y. T. C. (2019). Promoting college student's learning motivation and creativity through a STEM interdisciplinary PBL human-computer interaction system design and development course [Article]. Thinking Skills and Creativity, 31, 110. https://doi.org/10.1016/j.tsc.2018.09.001

Leggett, N. (2017). Early childhood creativity: challenging educators in their role to intentionally develop creative thinking in children. Early Childhood Education Journal, 45(6), 845-853. https://doi.org/https://doi.org/10.1007/s10643-016-0836-4

Lindqvist, G. (2003). Vygotsky's theory of creativity. Creativity Research Journal, 15(2-3), 245251. https://doi.org/https://doi.org/10.1080/10400419.2003.9651416

OECD. (2020). Education in the Western Balkans: Findings from PISA. O. Publishing.

Ong, E. T., Ayob, A., Ibrahim, M. N., Adnan, M., Sheriff, J., \& Ishak, N. (2016). Integrating STEM into Early Childhood Education: Is it feasible? The Eurasia Proceedings of Educational Social Sciences, 4, 336-341.

Rasul, M. S., Zahriman, N., Halim, L., \& Rauf, R. A. (2018). Impact of integrated stem smart communities program on students scientific creativity. Journal of Engineering Science Technology, 13, 80-89.

Shukri, A. A. M., Ahmad, C. N. C., \& Daud, N. (2019). Pelaksanaan Modul Celik STEM Bagi Memperkasakan Pemikiran Kreatif Murid Tingkatan Satu. International Journal of Education, Psychology and Counseling, 4(32), 219-237.

Siew, N. M., \& Norjanah Ambo. (2018). Development and evaluation of an integrated projectbased and stem teaching and learning module on enhancing scientific creativity among fifth graders. Journal of Baltic Science Education, 17(6), 1017.

Sirajudin, N., Suratno, J., \& Pamuti. (2021). Developing creativity through STEM education. Journal of Physics: Conference Series,

Stylianidou, F., Glauert, E., Rossis, D., Compton, A., Cremin, T., Craft, A., \& Havu-Nuutinen, S. (2018). Fostering inquiry and creativity in early years STEM education: Policy recommendations from the Creative Little Scientists Project. European Journal of STEM Education, 3(3).

Torrance, E. P. (1977). Creativity in the Classroom; What Research Says to the Teacher. Retrieved 28 March 2020, from http://files.eric.ed.gov/fulltext/ED132593.pdf

Treffinger, D. J. (1985). Review of the torrance tests of creative thinking (J. V. Mitchell Jr., Ed. The ninth mental measurements yearbook ed., Vol. 2). University of Nebraska, Buros Institute of Mental Measurements. 